\title{
THE INFLUENCE OF SERVICE QUALITY ON CUSTOMER TRUST AND COMMITMENT AND ITS EFFECT UPON CUSTOMER OF SAVING SERVICE LOYALTY AT BPD SULTRA MAIN BRANCH
}

\author{
Yusuf Hayat \\ Faculty of Economics, University of Haluoleo, Kendari, Indonesia \\ E-mail: hayatyusufabadi77@gmail.com
}

\begin{abstract}
This study aims to examine and analyze: (1) The influence of service quality on customer trust at BPD Sultra Main Branch; (2) The influence of service quality on customer commitment at BPD Sultra Main Branch; (3) The influence of trust on customer loyalty at BPD Sultra main Branch; and (4) The influence of commitment on customer loyalty at BPD Sultra Main Branch. This study used 121 samples of saving service costumers at BPD Sultra Main Branch. Data analysis methods were descriptive statistics and inferential statistics, and analysis tool used was Structural Equation Modelling (SEM) and AMOS program package version16.0. The results showed that: (1) the service quality has positive influence over the customer trust, (2) the service quality has positive influence over the customer commitment, (3) the trust has positive influence over the customer loyalty, and (4) the customer commitment has positive influence over the customer loyalty.
\end{abstract}

\section{KEY WORDS}

Service quality, trust, commitment and customer loyalty.

Nowadays, global competition is inevitable phenomenon in the business world. It is marked by fast changes in communication industry, information, and technology. The same goes for a banking sector.

The effect of competition at Indonesian banking industry was that in 1997-2000 there were tens of banks liquidated and the rest were merged since the continuously loss experienced by several banks either stated or private-owned lender. Customer trust towards national banking drastically decreases and causes the number of customers withdraw their funds from those banks. This incident shows that in managing bank it should be executed professionally by considering the problem faced by banking sector, i.e., (1) Bank has to pursue growth and expansion, (2) Bank is demanded to give an accurate and high service, (3) technological advancement, (4) funds structural change, and (5) competition.

Such complexity of the problems in the banking world rise to challenge for banking growth such as management guidance, the quality of service and knowledge about the marketing of banking services. Determination of service strategy and bank performance is extremely important to be paid attention. When customer trusts with performance offered by bank, then he/she will pay it with perform transaction repeatedly.

A high level of bank competition lets the customers free to decide, so that bank has to be willing to give the most appropriate service like the customer wants. Additionally, today's customer demands are various at which supported by higher educational background and easiness to get information, thus his/her demand and flexibility becomes high too. Pace, safety, convenience and friendliness in service are more required by customers to decide an option of banking service aside from interest rate, price rate and affordable cost of service. For that reason, bank competing each other tries to improve its service quality in order to fulfill customers demand.

The same goes for BPD Sultra Main Branch which has to compete with other banks operating in Kendari area. According to the Banks Performance Rank issued by Bank Indonesia Kendari Representative Office in December 2010, the rank of BPD Sultra upon commercial banks in Kendari is in the second position of 15 commercial banks based on the number of loan to deposit (DPK) coming from saving, credit transfers, and deposits. From the 
DPK BPD Sultra above, amount of DPK from BPD Main Branch contributes $41.08 \%$ of the amount of the whole DPK. This means that a half of DPK at BPD Sultra is owned by BPD Sultra Main Branch. However, DPK got during 3 years (2009-2011), shows that growth of saving funds is still categorized to be small compared to deposits and credit transfer.

As the biggest branch office and supported by facilities and more complete personnel, BPD Sultra Main Branch should be able to get higher DPK from community. Creation of good service can be damaged by bad service delivery or marketing system. Since the negative publication of the service, BPD Sultra Main Branch tries to clear things away in order to improve the service so it can enhance customer trust and commitment that in the end will improve customer loyalty to bank.

But then the influence of service quality on trust and commitment and its effect on customer loyalty is sometimes different. Several previous studies shows gap in the result. Agung (2006) found that service quality has significant influence over the loyalty, while Parawansa (2012) discovered that it has not direct significant effect upon the quality but being mediated by trust, satisfaction and commitment. Furthermore, Ndubisi (2006) found that trust and commitment has significant influence to increase customer loyalty, and Handayani (2008) discovered that trust did not increase loyalty significantly. In other words, even though customer trusts to company, it does not mean that he/she is loyal too.

According to the explanation above, thus this study tries to learn the influence of service quality, customer trust, customer commitment and its effect on customer loyalty.

\section{CONCEPTUAL FRAME AND HYPOTHESIS}

Service quality is critical to hold customer to make him stay. Bank has to try it best to create and improve its customer loyalty by providing quality service. The service quality consists of completeness and physical appearance of service at bank (tangibles), fast and accurate process of service (reliability), the way bank officer serves customer is responsive, polite, and friendly (responsiveness), ensuring the confidentiality of customer data, problem solving as sworn, and the sincere attention (empathy) shown by bank officer to customer's complaint. The whole form of this service is meant to fulfill needs, desires and wishes of customer.

The customer faith that bank able to meet their need, desire and wish raises the sense of belief to bank. Trust does not just come but it has to be cultivated in a long term and in every event at which the customer uses the bank service. Bank has to make customer sure that product or service offered is fit to the need and wishes of customer, and bank has good reputation to keep data secret and is consistent in giving and maintaining service quality provided.

When customer trusts in bank performance and reputation grows, the opportunity to get customer using banking service is higher. Customers will more choose to save their funds at a bank which has big benefit and good reputation which will protect them from risk. This trust factor becomes a fundamental thing which has to be paid attention by bank since this kind of business is a trusty business. Once bank is able to gain customer trust, then at that time it gets his/her loyalty. In line with the trust that is grown continuously by bank, later on it will shape strong commitment from customers to maintain good relationship with bank. As a result, trust is critical to be considered since it becomes an element giving positive influence towards customer commitment. Customer trust is shown by attitude or behavior that is related to bank. A committed customer will always have and build invaluable relationship in the exchange he/she does. It happens since customer feels a big benefit in that exchange so they will always be there in the cooperation relationship. The existence of customer in the partner exchange is proven with their identity using product and service offered by bank. In addition, the loyal customer will kindly tell their positive experience related to the product and service that has been accepted to the other sides. In a long term it will increase bank reputation.

Having a loyal customer is a dream of every bank. The key to get is through fulfilling desires and wishes. The more banks can fulfill the customer desires or even over his/her 
expectation, the more customers does not want to move to another bank and s/he will be more committed to use bank's service at which it shows customer loyalty to bank. For that reason, the improvement of service quality at BPS Sultra Main Branch brings positive influence. follow:

Starting from the problem and frame of mind, then the hypothesis proposed is as

1. There is an influence of service quality on customer trust at BPD Sultra main branch.

2. There is service quality influence on customer commitment at BPD Sultra main branch.

3. There is customer trust influence on customer loyalty at BPD Sultra main branch.

4. There is an influence of customer commitment on customer loyalty at BPD Sultra main branch.

\section{METHODS OF RESEARCH}

According to the problem and goal which want to reach, then this was an explanatory research that explained causal relationship of service quality influence on customer loyalty through trust and commitment by conducting a hypothesis test.

This research was conducted at BPD Sultra Main Branch during two months. Population of this research was all of customers of saving service amounting to 6.195. It was divided into 4 clusters which is appropriate to type of saving service at BPD Sultra Main Branch, i.e., Tabungan Simpeda (non-saving service for civil servant salary), Tabungan Tapelra, Tabungan Tahara and TabunganKu. The number of sample of this study was calculated based on the formula of Husein (2005):

$$
n=\frac{\mathrm{N}}{1+\mathrm{N}(\mathrm{e})^{2}}
$$

Where: $n=$ the number of sample; $\mathrm{N}=$ the number of population; $\mathrm{e}=$ relaxation percentage of inaccuracy (precision) due to fault.

With a precision level of $9 \%$ and considering that the number can meet the criterion in the application of Structural Equation Modeling (SEM) in which the respondent must be between 100-200 (Hair et al. in Ferdinand, 2006), thus the number of sample used was 121 customers of saving service.

Variable of this research was consisted of exogenous/independent variable, is variable of service quality stated by $\mathrm{X}_{1}$; intervening Endogenous variable, is variable of trust stated by $\mathrm{Y}_{1}$ and commitment variable stated by $\mathrm{Y}_{2}$; endogenous/Dependent variable, is a loyalty variable stated by $Y_{3}$.

Data Types and Sources used in this research were primary data was acquired directly from respondent, and secondary data was acquired from internal data resources such as general description of bank, the number of employees and structure of an organization, journals and books related to the research object.

Data collection method used in this study was through spreading questionnaire to respondents; interview, was directly performed to bank officer and customer.

Data measurement used likert scale which measured dependent and independent variable. Those five likert scale are Strongly Agree (score 5), Agree (score 4), Neutral (score 3), Disagree (score 2), Strongly disagree (score 1).

Definition of Variable Operational. Based on the theoretical study, then made an operational definition of the variable referred in this study:

1. Service quality is a customer assessment upon BPD Sultra Main Branch based on the dimension of tangible, reliability, responsiveness, assurance and empathy.

a. Tangibles based on the customer assessment upon physical appearance of office facilities and bank officers providing coziness to customers is measured using indicators: 
- Cleanliness of office room;

- Availability of parking area;

- Queue number availability;

- Bank officer appearance is neat.

b. Reliability based on the customer assessment on bank officer ability and reliability in providing service is measured using indicators:

- Ability to understand customer needs;

- Reliability to handle customer complaints;

- Accuracy to process transaction.

c. Responsiveness based on the customer assessment on bank officer friendliness and speed is measured using indicators:

- Bank officer friendliness;

- Bank officer courtesy;

- Speed of service.

d. Assurance based on the customer response on the guarantee of professionalism, data secret, and problem solving of complain is measured using indicators:

- Guarantee of bank officer professionalism attitude;

- Guarantee of customer data secret;

- Guarantee of problem solving.

e. Empathy based on the customer assessment on the way of bank officer communicates, pays attention, and listens to customer complaint is measured using indicators:

- Bank officer way to communicate;

- Bank officer attention to customers;

- Bank officer willingness to listen customer complaint.

2. Customer trust is a customer measurement on BPD Sultra Main Branch based on the dimension of shared value, communication and opportunistic behavior.

a. Shared value at which customer believes to product, system, and technological ability used by bank is measured using indicators:

- Believe to the benefit of product;

- Believe to the banking system security;

- Believe to the banking technology capability.

b. Communication happens when customer believes that bank is opened in providing information, it is measured using indicators:

- Believe to bank officer knowledge on the product;

- Believe to the bank officer knowledge to explain banking products;

- Believe that bank officer will speak with understandable word choice.

c. Opportunistic Behavior is when customer believes to bank reputation and are protected by regulation, it is measured using indicators:

- Believe that bank has good reputation in providing service;

- Believe that Bank has good reputation in solving the problem arises;

- Believe on the Banking laws that protect customer interest.

3. Customer commitment is maintaining cooperation relationship between customer and BPD Sultra Main Branch continuously on the basis of mutual trust and benefits gained. Variable of commitment in this study used three indicators, they are:

- Wish to remain have relationship;

- Desire to cultivate relationship;

- Belief in the relationship stability.

4. Customer loyalty is customer assessment on BPD Sultra Main Branch according to the dimension of trust, psychological commitment, switching cost, word of mouth, and cooperation.

a. Trust is customer faith on BPD Sultra Main Branch measured by using indicators:

- Believe in bank management; 
- Believe in the consistency of banking service;

- Believe in the trust fulfillment.

b. Psychological commitment is the feeling of emotional connection, the sense of belonging and the willingness to remain a service user, it is measured using indicators:

- The sense of having emotional connection upon bank as a regional bank;

- The sense of belonging of the sustainability of regional bank;

- A willingness to use another service in the future.

c. Switching cost is customer assessment on charge and difficulty experienced when using another bank service, it is measured using indicators:

- Maintenance fee of another bank is higher;

- Maintenance fee of another service at another bank in higher;

- Registration process at another bank is longer.

d. Word of mouth is customer willingness to recommend, persuade, and inform positive thing about BPD Sultra to others. The indicators are:

- Ready to recommend BPD Sultra to others;

- Ready to persuade others to become customer of BPD Sultra;

- Ready to inform positive thing about BPD Sultra to others.

e. Cooperation is a customer willingness to cooperate with BPDS Sultra, the indicators are:

- Having willingness to give suggestion and idea to enforce banking service;

- Ready to participate in the activity of social service performed by bank;

- Ready to participate to promote bank.

Instrument Validity and Reliability Test. Instrument validity examination was performed by intercorrelation test and if the probability value of $r<0.05$ then the item concerned is valid. While instrument reliability test was performed through considering alpha cronbach coefficient and if $\alpha>0.06$ then the research instrument was valid. Questionnaire was randomly spread to the candidate of respondents amounting to $30 \%$ until $50 \%$ of the total samples used in this research, thus the researcher spread questionnaire to 36 respondents. Result of instrument validity and reliability test was valid and reliable.

The method used to answer hypothesis was Structural Equation Model through the help of Software Amos version 16.0.

After conducting confirmatory test and model fit test, then the next stage is direct and indirect effect test. Direct effect test was carried out through comparing Critical Ratio fee and Standardized Regression Weight, and direct effect between compensation variable and promotion upon work spirit and employee performance. If the value of Critical Ratio is 2.0 at the level of mistake $\alpha=5 \%$, then indirect effect test sees beta coefficient value or Standardized Indirect Effect compared to Standardized Total effect, and significance value of indirect effect got from multiplying direct effect significance value by indirect effect significance value.

Research Hypothesis Test. Hypothesis test was conducted by comparing probability significant value of a causality relationship with $\alpha=0.05$. If the value of probability significance of a causality relationship is $\alpha=0.05$, then the hypothesis proposed is accepted. Conversely, If the value of probability significance of a causality relationship is $\alpha=0.05$, then the hypothesis proposed cannot be accepted.

\section{RESULTS AND DISCUSSION}

According to the factor confirmatory analysis test, loading factor value is presented in Table 1. Analysis of direct effect between construct of a model can be compared to evaluate relation of each construct upon the direct effect that the test results are presented in Table 2.

Service quality referred in this study is customer assessment on Bank based on the dimension of tangible, reliability, responsiveness, assurance and empathy, in this case is something can cultivate customer trust. 
According to the CFA test result, the highest loading factor of service quality $(X)$ variable is reliability $\left(X_{2}\right)$ and the highest loading factor of reliability $\left(X_{2}\right)$ is indicator of bank officer ability to understand customer need $\left(X_{2.1}\right)$ by 0.724 . While the highest loading factor of trust $\left(Y_{1}\right)$ is communication $\left(Y_{1.2}\right)$ and the highest loading factor of communication is in the indicator of customer trust of bank officer knowledge on banking products $\left(Y_{1.2 .1}\right)$ by 0.800 .

The connection between reliability $\left(X_{2}\right)$ and communication $\left(Y_{1.2}\right)$ is: when bank officer is able to understand what customer need, being reliable to handle customer complain and meticulous to process transaction, then it will grow customer trust on bank officer. Customer will believe that what bank officer says right, customer can ask for information all the time and bank officer will be opened to answer clearly so that will be easy to be understood by customer. For that reason, employee reliability of BPS Sultra Main Branch when serving customer will grow customer trust on communication aspect performed by bank officer.

Table 1 - Test Result of Confirmatory Factor Analysis Test

\begin{tabular}{|l|c|c|c|c|}
\hline \multicolumn{1}{|c|}{ Variable } & Loading Factor $(\lambda)$ The Highest & \multicolumn{2}{c|}{ Loading Factor $(\Lambda)$ The Lowest } \\
\hline Service Quality & reliablity & 0,987 & tangible & 0,685 \\
\hline Trust & communication & 0,962 & shared value & 0,561 \\
\hline Commitment & Faith of relationship stability & 0,863 & Desire to maintain relationship & 0,806 \\
\hline Loyalty & Psychological Commitment & 0,858 & switching cost & 0,658 \\
\hline
\end{tabular}

Table 2 - Test Result

\begin{tabular}{|l|c|c|c|c|}
\hline \multicolumn{1}{|c|}{ Independent Variable } & Dependent Variable & $\begin{array}{c}\text { Coefficient Effect of } \\
\text { Path Direct }\end{array}$ & (P Value) & Description \\
\hline Service Quality & Trust & 0,899 & 0,019 & Sig \\
\hline Service Quality & Commitment & 0,737 & 0,003 & Sig \\
\hline Trust & Loyalty & 0,481 & 0,029 & Sig \\
\hline Commitment & Loyalty & 0,448 & 0,008 & Sig \\
\hline
\end{tabular}

The connection between bank officer ability to understand what customer wants $\left(X_{2.1}\right)$ upon customer trust of bank officer knowledge related to the banking product $\left(Y_{1.2 .1}\right)$ is: when bank officer helps customer to choose product fit to his/her need, then customer will believe that bank officer has knowledge on product offered such as the superiority of a product, requirement needed, and how the process and procedure of registration. Thus, employee ability of BPD Sultra Main Branch in understanding customer need makes customer trusts that bank officer has big knowledge on banking products.

According to the descriptive analysis result, the highest score for answer of service quality $(X)$ variable is at empathy $\left(X_{5}\right)$ dimension by 4.12. While the highest answer score of trust $(\mathrm{Y} 1)$ variable is at shared value $\left(\mathrm{Y}_{1.1}\right)$ dimension. The connection between empathy $\left(\mathrm{X}_{5}\right)$ and shared value $\left(Y_{1.1}\right)$ is: when bank officer pays attention customer, being able to build good communication by giving short description in clearly and completely, shows how to use technological-based facilities (i.e., ATM using, PIN replacement, SMS banking, etc.), having willingness to listen and help to solve customer problem, so that customer will believe to the shared value. For that reason, empathy shown by employee of BPD Sultra main branch makes customer believes to the shared value of BPD Sultra main branch.

Empirical data shows that the average respondent's answer to each item statement used to measure each indicator of service quality variables dimention is majority agree. This means that based on experiences which have been felt by respondents so far they agree that the quality of services provided by BPD Sultra Main Branch is already quite good so it has been able to foster a sense of trust to BPD Sultra Main Branch.

This research result is supported by idea of Cronin et al. (1992); Morgan and Hunt (1994); Foster and Codogan (2000), Parawansa (2012); and Agung (2006) who stated that service quality has positive and significant influence on trust variable.

The Influence of Service Quality on Commitment. According to the CFA test result, the highest loading factor of service quality $(X)$ is reliability $\left(X_{2}\right)$ and the highest loading factor of reliability $\left(X_{2}\right)$ is indicator of bank officer ability to understand customer need $\left(X_{2.1}\right)$ by 0.724 . 
While the highest loading factor of commitment $\left(\mathrm{Y}_{2}\right)$ variable is indicator of trust to keep maintaining relationship $\left(\mathrm{Y}_{2.3}\right)$ by 0.863 .

The connection between bank officer ability to understand customer need $\left(X_{2.1}\right)$ upon indicator of trust to keep maintaining relationship $\left(\mathrm{Y}_{\cdot 2.3}\right)$ is when bank officer able to help customer to choose product fit to his/her want, then customer will be remain sure to maintain relationship stability. Thus, employee ability of BPD Sultra Main Branch in understanding customer need makes him sure to remain establishes cooperation relationship with BPD Sultra Main Branch.

Based on the descriptive analysis, the highest answer score of service quality $(X)$ variable is at empathy $\left(X_{5}\right)$ dimension by 4.12 . While the highest answer score of commitment variable $\left(\mathrm{Y}_{2}\right)$ is 3.85 .

The connection between empathy $\left(X_{5}\right)$ upon connection is: when bank officer cares to customer, able to establish good communication by explaining a product clearly and completely, showing the way to use technological-based facilities (i.e., ATM use, PIN replacement, SMS banking, etc.), able to listen and help solve customer problem, so that customer who feel that his/her interest has been fulfilled does not want to move to another bank. This means that customer has intention and will to cultivate cooperation relationship with bank. Thus, empathy shown by employees of BPD Sultra main branch makes customer want to have commitment to keep maintaining relationship with bank.

From the description above, it appears that the service quality variable has a positive and significant influence over the customer commitment variable at the BPD Sultra Main Branch. Empirical data shows the average respondent's answer for each item of the commitment variable statement is in positive / good area, which means that based on the experience which has been felt by respondents so far they agree that the quality of services provided by BPD Sultra Main Branch is already quite good so it has been able to cultivate the commitment of customers at BPD Sultra Main Branch.

This research result is supported by the findings of Indarto (2006), Agung (2006) and Parawansa (2012) who stated that service quality has positive and significant influence over the commitment variable.

The Influence of Trust on Loyalty. Trust referred in this research is assessment of customer of saving service upon BPD Sultra Main Branch based on the dimension of shared value, communication and opportunistic behavior, in this term is bringing influence to customer loyalty.

According to the confirmatory factor, the highest loading factor of trust variable $\left(Y_{1}\right)$ is communication dimension $\left(Y_{1.2}\right)$ and the highest loading factor of communication dimension is indicator of customer trust of bank officer knowledge While the highest loading factor of the loyalty variable $\left(\mathrm{Y}_{3}\right)$ is the dimension of psychological commitment $\left(\mathrm{Y}_{3.2}\right)$ and the highest loading factor of the psychological commitment dimension is indicator of the sense of belonging to the development of the bank $\left(\mathrm{Y}_{3.1 .1}\right)$ with a value of 0.794 .

The link between the dimensions of communication $\left(\mathrm{Y}_{1.2}\right)$ to the psychological commitment $\left(\mathrm{Y}_{3.2}\right)$ dimension is: when the bank officer communicates with the customer, In addition to providing information about bank products, bank officials also educate customers about the role of BPD Sultra as a financial institution owned by local governments to foster emotional bonds of belonging feelings to the regional assets. Thus, the form of communication made by employees of BPD Sultra Main Branch play a role in fostering psychological feelings to commit to the bank by looking at BPD Sultra as a valuable asset belonging to the region.

The connection between indicator of customer trust to bank officer knowledge of banking product $\left(\mathrm{Y}_{1.2 .1}\right)$ and responsibility feeling on the development of regional bank $\left(\mathrm{Y}_{3.1 .1}\right.$ ) is: bank management chooses to place employees who have sufficient level of knowledge and able to communicate well with customers so that that generally selected employees who come from local tribes. Bank officer knowledge around banking products and services as well as regional knowledge is expected to create a psychological bond to customers to come to love and feel responsible for the development of BPD Sultra as part of the region. Thus, the existence of employees of BPD Sultra Main Branch with adequate level of knowledge about 
banking and regional can evoke emotional customers to feel responsible for the development of BPD Sultra Main Branch as part of the asset area that should be maintained.

Empirical data shows the average of respondents' answers to each item statement of the trust variable is in the positive / good area. Customers have confidence in BPD Sultra Main Branch which is shown by customers believe in the benefits of savings products used, banking systems run by is secure which means customers believe that their money is safe, and customers believe in the banking technology capabilities used by BPD Sultra Main Branch.

The results of this study are supported by the findings of Ndubisi (2006), Sulistiarini (2007) and Parawansa (2012) which stated that trust has a positive and significant influence over the loyalty variable.

The Influence of Commitment Upon Loyality. Customer commitment in this research is continuously maintaining customer relationship with service provider, that is, BPD Sultra Main Branch, based on mutual trust and benefit obtained.

Based on the result of confirmatory factor, the highest loading factor of the commitment variable $\left(Y_{2}\right)$ is an indicator of faith to keep maintaining relationship $\left(Y_{2.3}\right)$ by 0.863 . While the highest loading factor of the loyalty variable $\left(Y_{3}\right)$ is the dimension of psychological

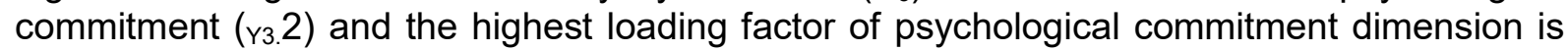
indicator of feeling responsible to the development of bank $\left(\mathrm{Y}_{3.1 .1}\right)$ by 0.794 .

The linkage between indicator of faith to keep establishing relationship $\left(\mathrm{Y}_{2.3}\right)$ and the sense of responsible for the development of bank $\left(Y_{3.1 .1}\right)$ is: when customer has faith to keep establishing relationship with bank since BPD Sultra is the paying bank of his/her salary and as a place where s/he can borrows funds, then customer has a sense of belonging to the sustainability of BPD Sultra for his/her benefit. Customer wants the existence of BPD Sultra Main Branch is maintained. So that the customer's belief that the partnership relationship will remain as well as make the customer takes responsibility for the existence and development of the bank in order to meet the interests of its own customers.

Based on the results of descriptive analysis, the highest score of the commitment variable $\left(Y_{2}\right)$ is in the faith indicator of relationship stability $\left(Y_{2.3}\right)$ by 3.96 and the highest response score of the loyalty variable $\left(Y_{3}\right)$ is at an indicator of trust in management $\left(Y_{3.1 .1}\right)$ by 4.06 .

The relationship between an indicator of faith for relationship stability $\left(Y_{2.3}\right)$ and the indicator of trust in management $\left(\mathrm{Y}_{3.1 .1}\right)$ is: when the customer is confident with the partnership relationship that has been established with the bank, continue to use bank services which show customers also believe in the performance of bank management. So that the more confident customers to establish partnership relationship with BPD Sultra Main Branch, the more customers believe in the management of BPD Sultra Main Branch.

From the description above, it appears that the commitment variable has a positive and significant influence over the customer loyalty variables on BPD Sultra Main Branch. At which the increase of customer commitment on BPD Sultra Main Branch more cultivate customer loyalty on BPD Sultra Main Branch. This means that any change of commitment increase is in the same positive direction with the increase of customer loyalty.

Empirical data shows the average respondent's answer for each item statement of commitment and loyalty variable is in positive / good area. This means that based on customer commitment, respondents have shown their loyalty to BPD Sultra Main Branch.

The results of this study are supported by the theory of Morgan and Hunt (1994) which states that trust and commitment are key constructs relevant for any type related exchange. Ndubisi (2006), Agung (2006) and Parawansa (2012) which states that commitment has a positive and significant influence over the loyalty variable.

\section{CONSCLUSION}

Service quality has positive and significant influence to the customer trust, it means that the better the service provided, the higher the trust of customer to bank. Service quality improvement will increase customer trust to BPD Sultra Main Branch. 
Service quality has positive and significant influence over the customer commitment which means the better the service provided, the higher the commitment to establish cooperation relationship with bank. The change of improving service quality will enhance customer trust to BPS Sultra Main Branch

Customer trust has positive and significant influence over the customer loyalty, it means that the more trust the customer to the service provided by bank, the more loyal the customer. The change of improving service quality will increase customer loyalty over the BPD Sultra Main Branch

Customer commitment has positive and significant influence over the customer loyalty, it means that the more commitment customer to bank, the more loyal the customer. The change of customer commitment improvement will increase customer loyalty upon BPD Sultra Main Branch.

\section{SUGGESTIONS}

From the conclusion explained above, then the suggestions which can be given are as follows:

For BPS Sultra Management:

In order to increase customer trust to the bank services, it is necessary to develop more diverse product services such as electricity / water / telephone payment services, internet banking, debit card products and accelerate the implementation of Electronic Employee Cards (KPE) of civil servants. In addition, giveaway program will give an added value at customer's point of view. For that reason, the various services at bank along with giveaways program will make customer becomes the user of bank service in a long term;

Customer commitment needs to improve by intimacy approach, both kinship and personal. BPD Sultra's employee mostly coming from the local area is an important complimentary factor in establishing effective communication so cooperation relationship between customer and bank goes smothly and long lasting;

Providing training to improve service quality is not only limited to the officer at customer service and teller, but also involves security guard and cleaning service. So that the improvement happens at all area. Good service in the customer's point of view will improve bank positive value that results in costumer recommend it to others.

For The Future Researchers:

If using the same variable with this research, it is suggested to examine the direct effect between service quality variable upon customer loyalty as well as to study the indirect relationship of service quality variable upon loyalty through trust and customer commitment; levels;

To consider adding other variables such as satisfaction variables to measure loyalty

Extending research object to all customers of service users, not only customers of saving service, so that the illustration of the quality level of services is obtained thoroughly to all parts of services in the bank.

\section{REFERENCES}

1. Agung, K.H. (2006). Analisis pengaruh Kualitas Layanan, Komitmen dan Kepercayaan terhadap Loyalitas Konsumen (Studi Kasus Pada Nasabah Tabungan Simpeda Bank Jateng). Unpublished Thesis. Universitas Diponegoro, Semarang.

2. Cronin, J.J. and Steven, A. (1992). Measuring Service Quality: A Reexamination and Extention. Journal of Marketing, 56:55-68

3. Ferdinand, A. (2006). Structural Equation Modeling, dalam Penelitian Manajemen, Aplikasi Model-Model Rumit Dalam Penelitian Untuk Tesis Magister Dan Disertasi Doktor. BP UNDIP, Semarang.

4. Foster, B.D. and Cadogan, J.W. (2000). Relationship Selling and Customer Loyalty: An Empirical Investigation. Marketing Inteligence \& Planing, 18(44): 185-199. 
5. Handayani, S. (2008). Pengaruh Kepercayaan Dan Komitmen Terhadap Loyalitas Nasabah Pada PT.Bank Negara Indonesia (Persero) Tbk. Cabang Padang. Unpublished Thesis. Universitas Andalas, Padang.

6. Husein, U. (2005). Riset Pemasaran dan Perilaku Konsumen. PT.Gramedia Pustaka Utama in collaboration with Jakarta Business Research Center (JBRC), Jakarta.

7. Indarto, A. (2006). Pengaruh Factor-Faktor Pembentuk Komitmen Keterhubungan Nasabah Pada Sektor Perbankan. Unpublished Thesis. Universitas Gajahmada, Yogyakarta.

8. Morgan, R.M. and Hunt, S.D. (1994). The Commitment - Trust Theory of Relationship Marketing. Journal of Marketing, 58: 20-38.

9. Ndubisi, N.O. (2005). Relationship Marketing And Customer Loyalty, Marketing Intelligence \& Planning, 25(1): 98-106.

10. Parawansa, D.A.S. (2012). The Mediating Effect of Trust, Satisfaction, and Commitment On The Relationshiop Between Service Quality And Customer Loyalty in Islamic Banking of Indonesia. Universitas Hasanuddin, Makassar.

11. Sulistiarini, E. (2007). Pengaruh economic conten, resource content dan sosial content terhadap kepuasan, kepercayaan dan komitmen serta relationship intention Bank Sumatra Utara. Universitas Airlangga, Surabaya. 